\title{
Native Chicken Production in Indonesia: A Review
}

\author{
Produksi Ayam Lokal di Indonesia : Sebuah Ulasan
}

\author{
C. Hidayat and S. A. Asmarasari \\ Indonesian Research Institute for Animal Production, PO Box 221, Bogor 16002 \\ email : hidayat_c2p@yahoo.com \\ (Diterima: 2 November 2014 ; Disetujui: 2 Februari 2015)
}

\begin{abstract}
Indonesia is a country rich in native chicken genetic resources. There are 31 native chicken breed in Indonesia. Native chicken farming was developed for decades. In early period of 1907's, mostly farmers reared their native chicken by traditional system (about 80\%). In 1980s until now, the number of native chicken farmers which rear native chicken by semi intensive and intensive system have been increasing. These rearing system changing have significantly increased the native chicken productivity. The major constraints for the development of native chicken i.e. low growth rate, risks of high mortality, low egg production. Many research results stated that improving in breeding, feeding and management aspect will increase native chicken production. The information and data contained in this paper is the result of study literature for scientific papers, either in the form of journals, books, or proceedings, and livestock statistics books. This paper is made to support the development of native chickens in Indonesia.
\end{abstract}

Keywords: native chicken, production, Indonesia

\section{ABSTRAK}

Indonesia merupakan Negara yang kaya dengan sumber daya genetik ayam lokal. Berdasarkan hasil penelitian, terdapat 31 jenis ayam lokal yang ada di Indonesia. Peternakan ayam lokal berkembang dari masa ke masa. Dari semula lebih banyak dipelihara secara tradisional, pemeliharaan ayam lokal secara semi intensive serta intensive semakin banyak dilakukan. Perubahan pola pemeliharaan tersebut berimbas terhadap kinerja produksi ayam lokal. Produk pangan yang berasal dari ayam lokal memiliki posisi yang baik di hadapan konsumen, sehubungan memiliki cita rasa yang khas di mata konsumen. Dalam mengusahakan peternakan ayam lokal terdapat beberapa kendala yang menghambat kinerja produksinya diantaranya; tingkat pertumbuhan yang lambat, tingkat kematian yang tinggi, serta produksi telur yang rendah. Untuk meningkatkan kinerja produksi ayam lokal maka perlu dilakukan perbaikan pada aspek breeding, pakan, serta manajemen. Informasi dan data yang terdapat dalam makalah ini merupakan hasil studi pustaka terhadap karya tulis ilmiah, baik dalam bentuk jurnal, buku, proseding, serta buku statistika peternakan. Untuk mendukung upaya pengembangan ayam lokal di Indonesia maka makalah ini dibuat.

Kata kunci; ayam lokal, produksi, Indonesia

\section{INTRODUCTION}

Indonesia is a country which have rich in genetic resources, especially in the native chicken genetic resources (Sulandari et al., 2008). Iskandar (2011) stated that in the 1970s, most of the native chicken reared by traditional system (80\%), in which each farmer had approximately 30 heads. Since 1980s, Native chicken farms has been increased tremendously, farmers not only rearing their native chicken with traditional rearing 
system, but also implementing other rearing system (semi intensive and intensive).

Native chicken development in Indonesia is very important. As an animal protein source, native chicken has a significant role to providing more than 200 million Indonesian people requirement for animal protein. This condition gives the opportunity for native chicken stake holders to develop native chicken farms in Indonesia. Politically, the development of native chickens in line with Jokowi-Jusuf Kalla government agenda to achieve food self-sufficiency through controls on imports to food. Currently, the fulfillment of the national requirement to meat and egg chicken are largely sourced from broiler and layer chicken. Whereas seed of these chicken must be imported. According this condition, the development of native chickens as a source of animal protein national requirement is one way to achieve government's agenda in the field of food above. To support the development of local resources as a source of food, the authors try to presents the condition of native chicken productivity in Indonesia and how to develop native chicken production.

The information and data contained in this paper is the result of study literature for scientific papers, either in the form of journals, books, or proceedings, and livestock statistics book. Part to discussed in this paper are the history of native chicken in Indonesia, the types of native chicken in Indonesia, the role of native chicken in Indonesia, the existing condition of native chicken production in Indonesia, and ways to develop native chickens in Indonesia.

\section{History of Indonesian Native Chicken}

There are two theories that explain the origins of Indonesian native chicken. The first theory explains that native chicken originated from one ancestor (monophyletic origin). On the other hand, the second theory explains that native chicken come from several ancestors (polyphyletic origin) (Crawford, 1990).

Sulandari et al, (2008) revealed that Indonesian native chicken comes from domesticated process of the red jungle fowl. Muladno, (2008) believed that native chicken is historically the result of domestication of four wild chicken species: green wild chicken (Gallus varius), red wild chicken (Gallus gallus), Indian grey wild chicken (Gallus Soneratti) and Ceylon orange wild chicken (Gallus lavayetti). Sulandari et al. (2008) claimed that Indonesia is one of the main centre of chicken domestication in the world. Nataamijaya (2000) reported that there are 31 species (Table 1) native chicken in Indonesia.

\section{The Role of Indonesian Native Chicken}

Native chicken have a close relationship with Indonesian people life. In ancient times, native chicken were widely used as part of the Indonesian culture and customs (Sidadalog, 2007). Similarly with other developing countries, for Indonesian small holder farmers, native chicken represents one of the few opportunities for saving, investment and security against risk.

Based on their function, Nataamijaya, 2000 classified the Indonesian native chicken into several potential uses, such as; meat and egg producer, singing chicken, fancy chicken, used for traditional medicine and fighting cock (Table 1). Sartika and Iskandar, (2007) stated that Indonesian native chicken was classified into four functional groups i.e. singing chicken, used in traditional ceremonies, fancy and fighting Cock, meat and egg producer (Table 3 ).

\section{Native Chicken Condition in Indonesian}

Rearing system. Iskandar (2011) revealed that in the 1970s, the most of native chicken reared by traditional system $(80 \%)$, with each farmer had approximately 30 heads. In the 1980s until now, there are three types of native chicken rearing systems in Indonesia, such as: traditional, semi-intensive and intensive system. Changing of rearing system from traditional to semi intensive or intensive made a better effect on native chicken production.

According to study results, application of intensif rearing system improved productivity of native chicken (Table 4). Muladno (2008) made description of traditional, semiintensive, and intensive native chicken rearing system which showed on Table 2. 
Table 1. Native chicken breed and it is originate

\begin{tabular}{|c|c|c|c|c|}
\hline No & Breed Name & Breed Origin & Breed Characteristic & Breed role in the farmer \\
\hline 1 & Sentul & Ciamis West Java & $\begin{array}{l}\text { Sentul is main plumage color is grey which is it's typical general } \\
\text { appearance }\end{array}$ & Meat and egg producer \\
\hline 2 & Pelung & Cianjur West Java & $\begin{array}{l}\text { Pelung is the largest and the tallest body compared to other breeds, it } \\
\text { has also beautiful long crow which make it one of the most expensive } \\
\text { birds in Indonesia }\end{array}$ & $\begin{array}{l}\text { Meat produce, fighting cock } \\
\text { and Singing bird }\end{array}$ \\
\hline 3 & Kampung & $\begin{array}{l}\text { Found in most villages of } \\
\text { Indonesian archipelago }\end{array}$ & It is an ordinary chicken & Meat and egg producer \\
\hline 4 & Lamba & Southern Garut West Java & $\begin{array}{l}\text { Lamba has a slightly larger body size than Kampung chicken, with } \\
\text { long neck, single comb and longer crow compared to Kampung } \\
\text { chicken. }\end{array}$ & Meat and egg producer \\
\hline 5 & Wareng & Indramayu West Java & $\begin{array}{l}\text { This small size native chicken, It is very alert and difficult to catch, } \\
\text { however it has better egg productivity than another Kampung chicken }\end{array}$ & egg producer \\
\hline 6 & Banten & Banten & $\begin{array}{l}\text { The Banten has firm and compact posture, with short, small pea comb. } \\
\text { It has also a strong neck structure while its plumage is very similar to } \\
\text { that of Kampung chicken }\end{array}$ & $\begin{array}{l}\text { The Banten male chicken is a } \\
\text { game type of bird }\end{array}$ \\
\hline 7 & Ciparage & Karawang West Java & The male has a tall and solid body posture, is now practically extinct & Fighting cock \\
\hline 8 & Siem & $\begin{array}{l}\text { Found around Bogor and } \\
\text { Jakarta areas }\end{array}$ & $\begin{array}{l}\text { Siem chicken has a shiny blue black plumage, it's body size slightly } \\
\text { bigger than Kampung chicken. It is well known to have an excellent } \\
\text { mothering behavior }\end{array}$ & Egg producer \\
\hline 9 & Rintit/Walik & $\begin{array}{l}\text { The Rintit can be found } \\
\text { everywhere in Indonesia } \\
\text { although in very small } \\
\text { numbers }\end{array}$ & $\begin{array}{l}\text { This breed has a very distinctive appearance because it is plumage is } \\
\text { frizzled. }\end{array}$ & Fancy bird \\
\hline 10 & Nagrak & $\begin{array}{l}\text { Nagrak Sukabumi West } \\
\text { Java }\end{array}$ & $\begin{array}{l}\text { If is a cross breed of male Pelung and female Kampung which has } \\
87,5 \% \text { Pelung's blood and } 12,5 \% \text { Kampung's blood. It has a much } \\
\text { better growth rate than the Kampung and similar to Pelung. Nagrak } \\
\text { chicken is raised to be sold as meat type bird. }\end{array}$ & Meat producer \\
\hline 11 & White Kedu & $\begin{array}{l}\text { Kedu Temanggung Central } \\
\text { Java }\end{array}$ & $\begin{array}{l}\text { It has white plumage with big single comb on male's head. The } \\
\text { number of White Kedu is very small and it is impossible to gather a } \\
\text { rather big number of White Kedu, within short time due to its rarity }\end{array}$ & $\begin{array}{l}\text { It is needed to fulfill } \\
\text { requirement for certain old } \\
\text { traditional } \\
\text { activities }\end{array}$ \\
\hline 12 & Black Kedu & $\begin{array}{l}\text { Kedu Temanggung Central } \\
\text { Java }\end{array}$ & $\begin{array}{l}\text { It is flumage is almost thoroughly black with big single comb, the hen } \\
\text { lays more eggs than Kampung chicken hen. }\end{array}$ & $\begin{array}{l}\text { Egg and meat producer and } \\
\text { fighting/game }\end{array}$ \\
\hline 13 & Sedayu & $\begin{array}{l}\text { Sedayu Magelang Central } \\
\text { Java }\end{array}$ & $\begin{array}{l}\text { It has a better size and body weight than Kampung chicken. It is also a } \\
\text { good native layer, it is kept as egg producer at first year but after } \\
\text { around } 2 \text { years production period will be sold as a good meat type } \\
\text { native breed. }\end{array}$ & Egg and meat producer \\
\hline
\end{tabular}




\begin{tabular}{|c|c|c|c|c|}
\hline \multicolumn{5}{|c|}{ Continued } \\
\hline No & Breed Name & Breed Origin & Breed Characteristic & Breed role in the farmer \\
\hline 14 & Cemani & Temanggung Central Java & $\begin{array}{l}\text { Is Kampung or Kedu chicken which has a thoroughly balck color of } \\
\text { plumage, comb, wattles, tongue, skin, meat, leg scales and toes.. }\end{array}$ & $\begin{array}{l}\text { In Javanese society mainly, } \\
\text { Cemani birds are needed to } \\
\text { fulfill requirement for certain } \\
\text { old traditional ceremonial } \\
\text { activities, while some Chinese } \\
\text { medicine use the Cemani as } \\
\text { part of prescription }\end{array}$ \\
\hline 15 & Nusa Penida & $\begin{array}{l}\text { Bali Nusa Penida island } \\
\text { Bali }\end{array}$ & $\begin{array}{l}\text { It has a small body size and very alert. The male has thick neck } \\
\text { plumage, wide wings and considerably long tail feather, while the } \\
\text { female has a nice crest on top of the head. }\end{array}$ & Egg layer \\
\hline 16 & Olagan & Bali & $\begin{array}{l}\text { It has no feather on the neck while its body form tend to looked wider } \\
\text { than the Kampung. The plumage is very similar to that of Kampung } \\
\text { chicken. }\end{array}$ & Meat and egg producer \\
\hline 17 & Sumatera & Central region of Sumatera & $\begin{array}{l}\text { The male has a firm, compact and artistic body appearance with a long } \\
\text { beautifully curved tail feather. }\end{array}$ & $\begin{array}{l}\text { The female is also well known } \\
\text { as a good native egg type }\end{array}$ \\
\hline 18 & $\begin{array}{l}\text { Merawang } \\
\text { or Merawas }\end{array}$ & $\begin{array}{l}\text { Bangka Island South } \\
\text { Sumatera }\end{array}$ & $\begin{array}{l}\text { It has reddish brown color plumage (Merawang) or golden brown } \\
\text { (Merawas). The male has a big red single comb and wattles. }\end{array}$ & $\begin{array}{l}\text { The female known as a } \\
\text { productive layer. It is needed } \\
\text { to fulfill requirement for } \\
\text { certain old traditional } \\
\text { ceremonial activities }\end{array}$ \\
\hline 19 & Melayu & North Sumatera & $\begin{array}{l}\text { The male posture is big and firm with small short red pea comb. The } \\
\text { body plumage is not different from that of Kampung chicken }\end{array}$ & Fighting cock \\
\hline 20 & Balenggek & Solok West Sumatera & $\begin{array}{l}\text { It has three types i.e.,Gadang (big type), Batu (small type) and Ratiah } \\
\text { (medium type). Their body plumage mostly combination of red, black } \\
\text { and white. }\end{array}$ & Singing bird \\
\hline 21 & Tolaki & South Sulawesi & $\begin{array}{l}\text { It has an upright body posture small head, long neck and back, } \\
\text { supporter by a pair of long but strong legs. Its body plumage color is } \\
\text { not much different from the Kampung, yet it is very alert }\end{array}$ & $\begin{array}{l}\text { Meat and egg producer and } \\
\text { the game type native breed }\end{array}$ \\
\hline 22 & Nunukan & $\begin{array}{l}\text { Nunukan and Tarakan } \\
\text { Island East Kalimantan }\end{array}$ & $\begin{array}{l}\text { The male has a rather tall and big posture while it's female almost is } \\
\text { similar size with the Kampung. Nunukan has a more uniform plumage } \\
\text { color if compared with other breeds of native chicken. Male nunukan } \\
\text { has an extremely short tail feather which is the typical characteristic of } \\
\text { Nunukan breed }\end{array}$ & $\begin{array}{l}\text { It is needed to fulfill } \\
\text { requirement for certain old } \\
\text { traditional } \\
\text { activities }\end{array}$ \\
\hline 23 & Maleo & $\begin{array}{l}\text { Central Sulawesi and } \\
\text { Maluku Island }\end{array}$ & $\begin{array}{l}\text { The cock is tall and slender, with a big beak, blue faced and black crest } \\
\text { on its head make it looked very attractive. Its plumage basically black } \\
\text { and shinning reddish brown breast feather while it's tail feather is } \\
\text { white }\end{array}$ & - \\
\hline
\end{tabular}




\begin{tabular}{|c|c|c|c|c|}
\hline \multicolumn{5}{|c|}{ Continued } \\
\hline No & Breed Name & Breed Origin & Breed Characteristic & Breed role in the farmer \\
\hline 24 & Ayunai & Merauke Papua & $\begin{array}{l}\text { It has no feather on the neck and crop while its wattles are red and big. } \\
\text { Its body appearance tend to be round }\end{array}$ & Meat and egg producer \\
\hline 25 & Jepun & - & $\begin{array}{l}\text { The size of this breed is smaller than Kampung chicken, the cock has a } \\
\text { red single comb while the plumage color is about the same as that of } \\
\text { Kampung chicken. One typical characteristic is that it has a very soft } \\
\text { fluffy feather structure, looks like that the feathers are not grown well }\end{array}$ & - \\
\hline 26 & Bangkok & All area & $\begin{array}{l}\text { Actually most of "Bangkok" chicken kept by the farmers is crossbred } \\
\text { of pure male Bangkok with Kampung chicken. It has a tall, wide and } \\
\text { firm body with wide and strong wings, short red pea comb. The most } \\
\text { common plumage color is black with some red combination on the } \\
\text { neck, back, breast and wings for the adult male }\end{array}$ & Game bird \\
\hline 27 & Tukung & West Kalimantan & $\begin{array}{l}\text { It is possibly one of the rarest type of native chicken found in } \\
\text { Indonesia, male and female Tukung has no tail feather at all. The body } \\
\text { size usually smaller than Kampung chicken. }\end{array}$ & Fancy bird \\
\hline 28 & Bekisar & $\begin{array}{l}\text { Kangean Island, Madura, } \\
\text { East Java }\end{array}$ & $\begin{array}{l}\text { The most highly appreciated native chicken in Indonesia; it has a very } \\
\text { attractive shining body plumage. Its crow is very specific there fore it } \\
\text { is known as singing bird. Bekisar is a crossbred of male Green Jungle } \\
\text { Fowl with domestic fowl. The plumage color is very dependent on the } \\
\text { parent's plumage color }\end{array}$ & Singing bird \\
\hline 29 & Burgo & South Sumatera & $\begin{array}{l}\text { It is a crossbred of male Red Jungle Fowl with female Kampung } \\
\text { chicken. Brugo is very similar to dwarf chicken yet it has a slightly } \\
\text { bigger body size. }\end{array}$ & Fancy bird \\
\hline 30 & Kasintu & $\begin{array}{l}\text { Its scientific name is } \\
\text { Gallus-gallus bankiva lives } \\
\text { mostly in northern part of } \\
\text { Java, South Sumatera, Bali } \\
\text { and South Sulawesi }\end{array}$ & $\begin{array}{l}\text { The main plumage color of the cock are black, ornamented with red } \\
\text { color on its head, neck, back and waist. The hen usually has reddish } \\
\text { brown plumage color with some blackish stripes. }\end{array}$ & - \\
\hline 31 & $\begin{array}{l}\text { Canghegar/Cu } \\
\text { kir/Alas }\end{array}$ & $\begin{array}{l}\text { These wild birds live in } \\
\text { southern part of Java, } \\
\text { Madura and also in some } \\
\text { other Indonesian Island }\end{array}$ & $\begin{array}{l}\text { These are the native names for Green Jungle Fowl in Sundanese, } \\
\text { Madura and Javanese Languages. It has much smaller body size than } \\
\text { Kampung chicken. The body plumage of the cock basically black } \\
\text { combined with shiny green scaly looked plumage. It has a big round } \\
\text { rainbow colored single come with relatively long red wattles. The } \\
\text { hen's plumage color is pale brown with some small dark spots. }\end{array}$ & - \\
\hline
\end{tabular}

Source: Nataamijaya (2000; 2010) ; Sartika and Iskandar, (2007) 
Table 2. Description of traditional, semi-intensive, and intensive rearing system

\begin{tabular}{l}
\hline Rearing systems \\
\hline Traditional
\end{tabular}

Semi-intensive

Intensive

Description

Chicken from first day until death are allowed to live freely without farmers' intervention. It doesnot have particular feed provided, cage constructed, health management applied and technology implemented. All chicken activities are so natural. Chicken can roam around the house or anywhere else to seek food, breed and engage in other activities such as playing with other poultry and taking care of young chicken, but return home to the farmer's house at sunset. At night, they sleep in the trees around the house or in the kitchen. Farmers usually have 2-20 heads. In traditional rearing system, zero cost is needed in rearing native chicken to produce eggs or meat. Farmers' profits when selling chicken will be the absolute chicken price minus the day-old chick (DOC) price. The extensive system is thus considered economically beneficial for the farmers since they do not need to spend much money and energy on rearing them. This is the most popular management system in the countryside because most farmers, who are usually uneducated, have no capital or access to financial institutions and no capital to buy feed, supplements, or medicine. This system is considered less suitable for increasing productivity of native chicken, because it is difficult to control their feed consumption.

DOC chicken are housed in an open-fenced area, which resembles a ranch and is usually built in the backyard of the farmer's house. Farmers provide feed and drink regularly, but it is not routine medical treatment. In some cases, colony cages are provided to allow chicken to sleep at night; in most cases, there are no cages available and the chicken sleep everywhere on the farm. Theownership of chicken, varies from 25 to several hundred, are usually kept for noncommercial purposes, for urgent and basic needs such as school fees. Almost no technology is applied in this system.

The chicken population is classified on the basis of their life periods into 3 group: the starter (1 day-2 months); the grower ( 2 months -4.5 months); and the finisher ( $>4.5$ monthssold/slaughter). The chicken are kept in cages in animal houseseither litter or portal system and provided with feed, water, feed supplements and regular medical applications. The production is usually for commercial purposes and is fully business-oriented. Farmers are very experienced and usually have a wide network. Efficiency and productivity in their chicken business is given top consideration. The number of chicken kept varies from hundreds to thousands, depending on financial sources. 
Table 3. The type kind of Indonesian native chicken usage

\begin{tabular}{ll}
\hline Type group & Chicken breed \\
\hline Singing bird & Pelung, Bekisar, Kokok Balenggek, Gaok, Ketawa \\
Used in traditional ceremonies & Cemani, Black Kedu, White Kedu, Nunukan, \\
& Merawang \\
Fancy and fighting cock & Kate, Kapas, Mutiara, Poland/Kate Jambul, Serama, \\
& Bangkok, Sumatera/Melayu, Jalak Harupat, \\
& Bali/Olagan, \\
Producing meat and egg & Kampung, Kampung tolaki, Sentul, Arab, Kalosi, \\
& Wareng \\
\hline Source: Sartika and Isandar, (2007)
\end{tabular}

Source: Sartika and Iskandar, (2007)

Table 4. Native chicken performance with three different rearing systems

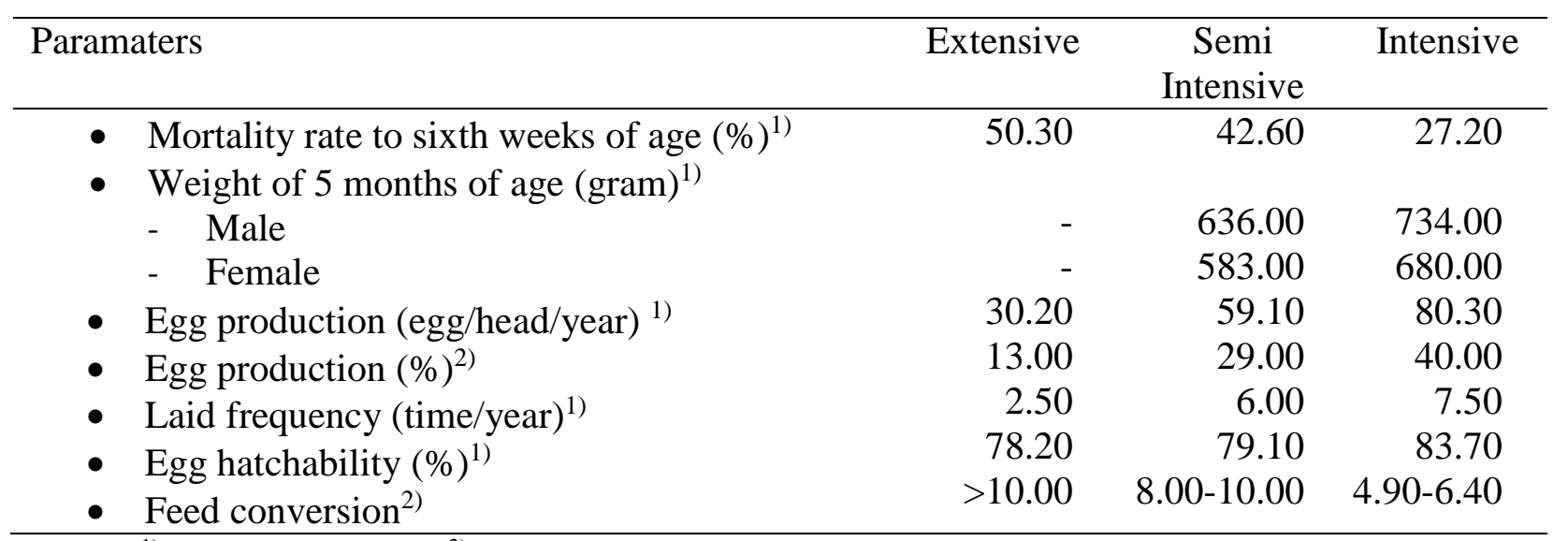

Source: ${ }^{1)}$ Sinurat et al, 1992; ${ }^{2}$ Diwyanto et al, 1996

Table 5. Performance of several Indonesian native chicken breed reared in intensive production system

\begin{tabular}{|c|c|c|c|c|c|}
\hline Parameters & Kampung & $\begin{array}{l}\text { Black } \\
\text { Kedu }\end{array}$ & $\begin{array}{l}\text { white } \\
\text { Kedu }\end{array}$ & Nunukan & Pelung \\
\hline \multicolumn{6}{|l|}{ Body Weight (gr/head) } \\
\hline - 4 week age & 148.00 & 165.00 & 140.00 & 151.00 & 161.00 \\
\hline - 12 week age & 708.00 & 575.00 & 739.00 & 665.00 & 669.00 \\
\hline - 20 week age & 1408.00 & 1480.00 & 1320.00 & 1203.00 & 1663.00 \\
\hline Age at first laying (days) & 151.00 & 138.00 & 170.00 & 153.00 & 165.00 \\
\hline Peak production $(\%)$ & 55.00 & 75.00 & 72.00 & 62.00 & 44.00 \\
\hline Average egg production (\%HDP) & 41.30 & 38.80 & 54.00 & 50.00 & 32.50 \\
\hline Average egg weight (gr) & 43.60 & 44.70 & 39.20 & 47.50 & 40.60 \\
\hline Average daily feed consumtion (gr) & 88.00 & 93.00 & 82.00 & 85.00 & 93.00 \\
\hline FCR (g feed/g eggs) & 4.90 & 3.60 & 3.80 & 3.60 & 7.10 \\
\hline
\end{tabular}

Source: Creswell and Gunawan (1982)

The number of households of native chicken farmer in Indonesia are 20.851.901 (Directorate General of Livestock Services, 2010). Percentage of native chicken farmer households by province from the largest to the lowest are mentioned respectively; in East
Java $(21.75 \%)$, Central Java (20.84\%), West Java (15.02\%), Lampung (4.87\%), Southern Sulawesi (4.39\%), North Sumatera (4.18\%), Banten (3.81\%), Southern Sumatera (2.76\%), East Nusa Tenggara (2.64\%), Yogyakarta (2.23\%), West Nusa Tenggara (2.15\%), 
Table 6. Population, meat and egg production of native chicken by province in Indonesia at year 2014

\begin{tabular}{|c|c|c|c|c|}
\hline No & Provinsi & Population (head) & $\begin{array}{l}\text { Native Chicken meat } \\
\text { production (ton) }\end{array}$ & $\begin{array}{l}\text { Native Chicken egg } \\
\text { production (ton) }\end{array}$ \\
\hline 1 & Aceh & 6.222 .882 & 13.047 & 2.646 \\
\hline 2 & North Sumatera & 16.475 .729 & 19.539 & 13.464 \\
\hline 3 & West Sumatera & 5.066 .861 & 6.208 & 3.236 \\
\hline 4 & Riau & 3.343 .227 & 3.490 & 1.627 \\
\hline 5 & Jambi & 12.212 .615 & 8.366 & 5.548 \\
\hline 6 & South sumatera & 5.803 .254 & 7.775 & 3.599 \\
\hline 7 & Bengkulu & 3.201 .972 & 514 & 1.158 \\
\hline 8 & Lampung & 11.945 .715 & 14.916 & 9.810 \\
\hline 9 & Bangka Belitung Island & 1.848 .171 & 1.383 & 2.329 \\
\hline 10 & Riau Island & 849.902 & 916 & 550 \\
\hline 11 & DKI Jakarta & - & 36.713 & - \\
\hline 12 & West Java & 26.740 .836 & 26.081 & 17.901 \\
\hline 13 & Central Java & 40.563 .963 & 45.215 & 36.517 \\
\hline 14 & D.I. Yogyakarta & 4.118 .660 & 5.669 & 2.667 \\
\hline 15 & East Java & 34.314 .067 & 39.348 & 18.827 \\
\hline 16 & Banten & 10.207 .278 & 9.345 & 13.617 \\
\hline 17 & Bali & 4.141 .144 & 4.715 & 2.992 \\
\hline 18 & West Nusa Tenggara & 5.082 .973 & 5.479 & 3.247 \\
\hline 19 & East Nusa Tenggara & 10.758 .054 & 11.517 & 4.579 \\
\hline 20 & West Kalimantan & 7.625 .982 & 15.215 & 3.981 \\
\hline 21 & Central Kalimantan & 3.420 .614 & 2.295 & 2.908 \\
\hline 22 & South Kalimantan & 8.779 .413 & 3.054 & 7.183 \\
\hline 23 & East Kalimantan & 7.272 .201 & 8.039 & 4.658 \\
\hline 24 & North Sulawesi & 2.322 .510 & 2.504 & 1.925 \\
\hline 25 & Central Sulawesi & 6.256 .758 & 10.789 & 4.051 \\
\hline 26 & South Sulawesi & 22.506 .968 & 6.643 & 12.323 \\
\hline 27 & Southeast Sulawesi & 10.508 .239 & 11.328 & 6.819 \\
\hline 28 & Gorontalo & 1.269 .568 & 1.398 & 939 \\
\hline 29 & West Sulawesi & 5.304 .177 & 5.718 & 3.434 \\
\hline 30 & Maluku & 3.874 .780 & 418 & 2.509 \\
\hline 31 & Southeast Maluku & 614.114 & 917 & 398 \\
\hline 32 & West Papua & 1.867 .756 & 1.366 & 643 \\
\hline \multirow[t]{2}{*}{33} & Papua & 2.017 .653 & 2.175 & 1.306 \\
\hline & Total & 286.538 .036 & 332.096 & 197.387 \\
\hline
\end{tabular}

Source : Directorate General of Livestock Services, 2014

West Kalimantan (1.88\%), Bali (1.87\%), West Sumatera $(1.60 \%)$, Riau (1.58\%), Southern Kalimantan (1.15\%), Jambi (1.03\%), Southeast Sulawesi $(0.83 \%)$, Central Sulawesi (0.74\%), Bengkulu (0.69\%), Central Kalimantan $(0.68 \%)$, Papua $(0.61 \%)$, East
Kalimantan $(0.57 \%)$, North Sulawesi $(0.44 \%)$, Jakarta $(0.40 \%)$, Bangka Belitung $(0.38 \%)$, Gorontalo (0.36\%), Maluku (0.27\%), North Maluku $(0.14 \%)$. Generally, the center of native chicken farmer household in the Java Island. 
The number of population, meat and egg production of native chicken by province in Indonesia showed in Table 6. According to Table 6, the number of total Indonesian native chicken population is 286.538.036 heads (Directorate General of Livestock Services, 2014). The big ten province of native chicken population percentage are mentioned respectively; Central Java (14.15\%), East java (11.97\%), West Java (9.33\%), South Sulawesi (7.85\%), North Sumatera (5.7\%), Jambi $(4.2 \%)$, Lampung $(4.16 \%)$, East Nusa Tenggara (3.7\%), Southeast Sulawesi (3.6\%), Banten (3.5\%).

According to The Directorate General of Livestock Services (2014), Indonesian native chicken contributes $11.13 \%$ of total national meat production of Indonesia. At present, the number of native chicken meat production in Indonesia is $332.100 .000 \mathrm{~kg}$ (Directorate General of Livestock Services, 2014). Big five provinces which contributing to native chicken meat production persentage in Indonesia were Central Java (13.61\%), East Java (11.84\%), Jakarta (11.05\%), West Java $(7.8 \%)$, and North Sumatera (5.88\%).

In 2014, native chicken egg production contributes $10.8 \%$ of total national egg production of Indonesia (Directorate General of Livestock Services, 2014). The latest number of total native chicken egg production in Indonesia was $197.387 .000 \mathrm{~kg}$. Similarly with native chicken meat production, native chicken egg production dominantly supplied by Central Java Province (18.50\%), East Java $(9.53 \%)$, and West Java (9.06\%). Entirely, Indonesia native chicken egg production by all province showed in Table 6 .

\section{Improvement Efforts for Better Per- formance}

Native chicken product has good brand in Indonesian market, so in Indonesia price of native chicken meat is more expensive than broiler meat. It is because the native chicken meat has specific texture, taste that preferred by most Indonesian people. Price of native chicken egg is also more expensive than layer egg. Beside to consumed, native chicken egg also used as part of traditional herbal medicine called "Jamu" which is very popular in Indonesia.

Nataamijaya, (2000) stated that the major constraints for the development of native chicken is low production performance, such as; low growth rate, resulting in small carcass percentage, low body weight, risks of high mortality to Newcastle disease, low body size and egg size, low hen day (percent) and hen housed (number) egg production, low rate of laying, high in feed cost.

Many result of researches reported that improving in breeding, feeding and management will increase native chicken productivity (Nataamijaya, 2010; Iskandar, 2005; Ketaren, 2010). Many study result stated that improvement in genetic quality through cross breeding or selection process has successfully improved the native chicken production (meat and egg) (Iskandar et al., 1998a, 1998, 1999; Sartika et al., 2004; Jarmani et al., 1998; Sidadalog et al., 1996). Beside through genetic approach, feeding systems also improved native chicken production (meat and egg) (Widjastuti, 1999; Nataamijaya et al., 2005; Nataamijaya, 2006). Several study result showed that using of management systems, namely; intensifycation rearing system with disease control improved native chicken production (Nataamijaya, 2000; Creswell and Gunawan, 1982; Sumanto et al., 1990; Rasyid, 2000; Sinurat, 1992).

\section{CONCLUSION}

In line with the current government vision which want to realize self-sufficiency in food. Development of native chicken is one of answers to this governments dreams. Indonesia is rich in native chicken genetic resources, that why, Indonesia has the opportunity to fulfill the majority requirement for meat and egg chicken. To develop native chicken, there are several constraints; low growth rate, high mortality, and low egg production. Native chicken productivity increased by improving the breeding, feeding, and management practice. 


\section{REFERENCES}

Crawford. R.D. 1990. Poultry breeding and genetic. Netherland, Elsevier science.

Creswell, D.C dan B. Gunawan. 1982. Ayamayam lokal di Indonesia: Sifat-sifat produksi pada lingkungan yang baik. Laporan No. 2. Balai Penelitian Ternak. Bogor. Indonesia. Pp 9-14.

Directorate General of Livestock Services. 2010. Statistical Book on Livestock. Direktorat Jenderal Bina Produksi Peternakan, Ministry of Agriculture, Jakarta..

Directorate General of Livestock Services. 2014. Statistical Book on Livestock. Direktorat Jenderal Bina Produksi Peternakan, Ministry of Agriculture, Jakarta.

Diwyanto, K., D. Zainuddin, T. Sartika, S. Rahayu, Djufri, C. Arifin, dan Cholil. 1996. Model pengembangan peternakan rakyat terpadu berorientasi agribisnis. Komoditi ternak ayam buras. Laporan. Dirjennak bekerjasama dengan balitnak, Bogor.

Iskandar, S. 2011. Optimalisasi protein dan energi ransum untuk meningkatkan produksi daging ayam lokal. Orasi Pengukuhan Profesor Riset Bidang Pakan dan Nutrisi Ternak. Badan Penelitian dan Pengembangan Pertanian, Kementerian Pertanian. Bogor 19 Juli 2011. $52 \mathrm{hlm}$.

Iskandar, S., D. Zainuddin, S. Sastrodihardjo, T. Sartika, P. Setiadi dan T. Susanti.

1998. Respon Pertumbuhan ayam Kampung dan ayam silangan Pelung terhadap ransum berbeda kandungan protein. Jurnal Ilmu Ternak dan Veteriner (JITV). 3(1):9-14.

Iskandar, S., H. Resnawati, D. Zainuddin, B. Gunawan dan Y.C. Rahardjo. 1998b. Performance "Pelung x Kampung" crossbred (pelung cross) meat type of chicken as influenced by dietary protein.
Bulletin of Animal Science, Suplement Edition: 539-546.

Iskandar, S., H. Resnawati dan D. Zainuddin. 1999. Karkas dan potongan bagian karkas ayam F1 silangan Pelung-Kampung yang diberi ransum berbeda protein. Jurnal Ilmu Ternak dan Veteriner (JITV). Vol 4(1): 28-34.

Iskandar, S. 2005. Pertumbuhan dan Perkembangan Karkas Ayam Silangan Kedu $x$ Arab Pada Dua Sistem Pemberian Ransum. Jurnal Ilmu Ternak dan Veteriner (JITV) 10(4): 253 - 259.

Jarmani, S.N., R. Dharsana, W.K. Sejati, E. Basuno dan B. Wibowo. 1998. Crossbred of ayam Kampung as an effort to meet the consumer need of ayam kampung in the future. Bulletin of Animal Science Supplement Edition: 427-431.

Ketaren, P.P 2010. Kebutuhan gizi ternak Unggas di Indonesia. Wartazoa 20 (4): 172-180.

Muladno. 2008. Native chicken genetic resources and production systems in Indonesia.GCP/RAS/228/GER Working Paper No. 6. Rome.

Nataamijaya, A.G. 2000. The native chicken of Indonesia. Bul. Plasma Nutfah 6(1): $1-6$.

Nataamijaya, A.G., A. Soetisna dan S. Rejeki. 2005. Kuantitas dan kualitas semen ayam kampung dan arab yang mendapat suplemen vitamin E (alpha-tocopherol). J. Anim. Prod. 7(2): 74-80.

Nataamijaya, A.G. 2006. Egg production and quality of kampung chicken fed rice bran diluted commercial diet and forages supplement. J. Anim. Prod. 8(3): 206-210.

Nataamijaya, A.G. 2010. Pengembangan potensi ayam lokal untuk menunjang peningkatan kesejahteraan petani. Jurnal Penelitian dan Pengembangan Pertanian 29(4): 131-138. 
Rasyid, T.G. 2002. Analisis perbandingan keuntungan peternak ayam buras dengan sistem pemeliharaan yang berbeda. Bull. Nutrisi dan Makanan Ternak 3(1): 1522.

Sartika. T., dan S. Iskandar. 2007. Mengenal plasma nutfah ayam Indonesia dan pemanfaatannya. Balai Penelitian Ternak. Pusat Penelitian dan Pengembangan Peternakan. Badan Litbang pertanian. Hal 93-94.

Sartika, T., S.S. Duryadi, A. Mansjoer, Syaefudin dan H. Martojo. 2004. Gen promotor prolaktin sebagai penanda pembantu seleksi untuk mengontrol sifat mengeram pada ayam kampung. Jurnal Ilmu Ternak dan Veteriner (JITV) 9(4): 239-245.

Sidadalog. J.H.P. 2007. Pemanfaatan dan kegunaan Ayam Lokal. Dalam K. Diwyanto dan S.N. Prijono (Ed.). Keanekaragaman Sumber Daya Hayati Ayam Lokal Indonesia: Manfaat dan Potensi. Pusat Penelitian Biologi, Lembaga Ilmu Pengetahuan Indonesia, Bogor. 27-42.

Sidadalog J.H, T. Yuwanta dan H. Sasongko. 1996. Pengaruh seleksi terhadap perkembangan sifat pertumbuhan, produksi dan reproduksi ayam kampung legund dan normal. Bull. Peternakan 20(2): 85 - 97.

Sinurat, A.P., Santoso, E. Juarini, Sumanto, T. Murtisari dan B. Wibowo. 1992. Peningkatan produktivitas ayam buras melalui pendekatan sistem usaha tani pada peternak kecil. Ilmu dan Peternakan 5(2). hlm. 73-77.

Sulandari, S., M.S.A. Zein and T. Sartika. 2008. Molecular characterization of Indonesian Indigenous chickens based on Mitochondrial DNA Displacement (D)-loop Sequences. Hayati J. Biosciences 15(4): 145 - 154.

Sumanto, E. Juarini, S. Iskandar, B. Wibowo, Ratnadi dan N. Rusmana. 1990. Pengaruh perbaikan tata laksana terhadap penampilan usaha ternak ayam buras di desa Pangradin. Suatui analisa ekonomi. Ilmu dan peternakan. 4 (3).

Widjastuti, T. 1999. Hasil-hasil penetasan ayam sentul pada dua sistem alas kandang yang diberi ransum dengan berbagai tingkat energy/protein. J. Pengembangan Peternakan Tropis: 9399. 